\title{
Towards a Talmudic Lexicon: The Aramaic Root p / q.f.y in the Light of a Story from the Babylonian Talmud
}

Uri Zur*

Ariel University

HACIA UN LÉXICO TALMÚdiCO: LA RAÍZ ARAMEA P. / Q.F.Y A LA LUZ DE UN RELATO DEL TALMUd DE BABILONIA.- El tratado Eruvin del Talmud de Babilonia cita tres historias y las presenta como un todo concatenado donde las tres comparten una sola característica: todas ellas recurren al «lenguaje de la sabiduría», como un medio atribuido a cada uno de los protagonistas de las historias. El presente artículo se centra en la primera de las historias de forma aislada de las demás, lo que proporciona un caso especial en relación con el estudio de la raíz aramea ו ק. q.f.y, a partir de la cual se forma la palabra / ve-titqfey, cuyo significado se discute en el presente trabajo.

Palabras Clave: Talmud de Babilonia; tratado Eruvin; léxico.

The tractate Eruvin of the Babylonian Talmud cites three stories, presented as a single concatenated whole, with all three sharing a single feature: they all have recourse to "language of wisdom" as a medium ascribed to each protagonist. The present article focuses on the first story in isolation from the others, placing emphasis on the Aramaic root I q.f.y as a special case in connection with studying, on the basis of which the Aramaic word ve-titqfey is formed.

Keywords: Babylonian Talmud; Tractate Eruvin; Lexicon.

\footnotetext{
"zuru01@walla.com
} 


\section{The Story in the Babylonian talmud}

The story in the sugya appears in tractate Eruvin, 53b of the Babylonian Talmud as follows:'

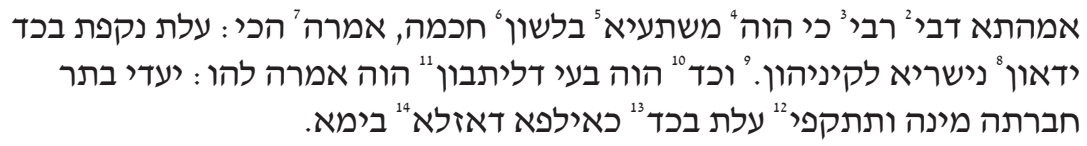

${ }^{1}$ The Hebrew text is based on Vilna edition $\left(19^{\text {th }} \mathrm{ACE}\right)$, and the annotated variants in the footnotes pertain to MS Munich 95 (France, 14 ${ }^{\text {th }}$ ACE), MS Oxford 366 (Spain, $14^{\text {th }}$ ACE), MS Vatican 109 (Italy, 12 - 13th ACE) and the Genizah Fragment Cambridge, Or. 1080, as well as other rabbinical sources like Y. iBN HabiB, 'En Ya'akov. Am Olam, ed. (Jerusalem 1961), R. H. BAR Hushiel, Commentary to bEruvin (Bene Beraq 1961 [in Hebrew]), N. Ben Yehiel, Aruch ha-shalem. A. Kohut, ed. (New York 1955) and R. Sh. YITZHAKI [=RASHI], Commentary to bEruvin (Bene Beraq 1961).

${ }^{2}$ In MS Munich 95 and MS Oxford 366 the word דבי / dvey is missing.

3. MS Munich 95: דרב / de-r.; MS Oxford 366-rabbi.

${ }^{4}$ MS Munich 95: כי הוו / ki havo.

${ }^{5}$ MS Munich 95 and MS Vatican 109: משתעיין / mishta'ayan; MS Oxford 366: משתמיא:mishta 'aya; IBN HABIB, 'En Ya'akov, Eruvin 53b: משתעיא / mishta'aya.

${ }^{6}$ Genizah Fragment: בלישן / be-lishan; MS Vatican 109 and MS Oxford 366 missed the letter: ב / be- (from the word leshon).

${ }^{7}$ MS Munich 95: אמרו / אמרן : amru; MS Vatican 109 / אמרו /amran; IBN HABIB, 'En Ya'akov, Eruvin 53b: אמרה / אמרה / amrah.

${ }^{8}$ Bar Hushiel, Commentary to bEruvin, 53b: יבעון / yiv'on; BEN YeHIEL, Aruch ha-

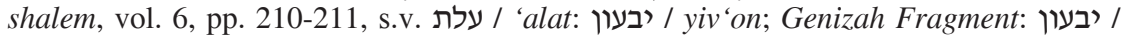
yiv'on; M. Ha-Meiri, Hidushey ha-meiri. S. Z. Broida ed. (3rd print, Jerusalem: Mossad Ha'rav Kook) Eruvin 53b: יבעון / yiv'on.

${ }^{9}$ BAR HushiEL, Commentary to bEruvin, 53b, adds: אתערו בתר חברתא מינה / eita'aru

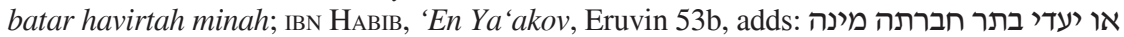
(כ) o yi 'ede batar havirtah minah ki

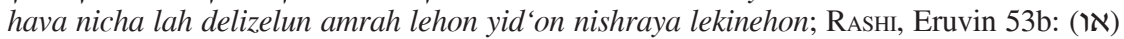

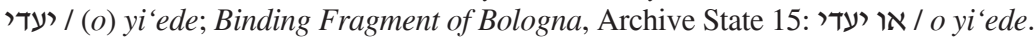

${ }^{10}$ Iвn HАBIB, 'En Ya'akov, Eruvin 53b: כי בעי / ki ba'ey.

דליתבון ${ }^{11}$ R. Rabbinovicz, Dikduke Sofrim (Jerusalem 1960) p. 204, n. 60 notes that I delitevun is missing in few versions.

${ }^{12}$ See the discussion below on the words: ותתקפי / ve-titqfey and ותתכפי / ve-titkfey.

${ }^{13}$ The word is doubtful in MS Munich 95; and in MS Oxford 366 (Ba-kad[a]) the word is apparently formed as a consequence of joining two last letters together.

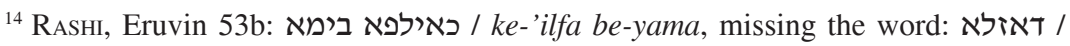


Translated, it would be read as: 'When the maidservant in the household of would engage in language of wisdom [enigmatic speech], she would speak in this way: The ladle strikes against the jar; let the eagles fly to their nests. And when she would want them to stay at the table, she would say to them: Let it [the cover] of her friend [the adjacent jar] be removed from her [it], and let the ladle float in the jar like a vessel that sails in the sea.' [All translations hereinafter are mine].

According to this account, the maidservant (or maidservants) in the house of Rabbi, when speaking (משתעיא/ mishta'aya) in "the idiom of wisdom" (that is, resorting to veiled forms of expression to keep outsiders from understanding), ${ }^{16}$ would say her piece in this way:

The ladle ${ }^{17}$ strikes the jar [of wine], ${ }^{18}$ let the eagles fly to their nests. And when she wanted (the students of Rabbi's house) to sit (meaning "to remain" ${ }^{19}$ ), she would say to them: Let [the lid (=the cover) of the wine barrel $\left.{ }^{20}\right]$ be removed from her [it], after her friend [the adjacent jar], and let the ladle float (or remain still) in the jar like a vessel plowing the sea.

de-'azelah; cf. Binding Fragment of Bologna, Archive State 15: כאוניה בים / ke-'oniya ba-yam.

${ }^{15}$ Onqelos' Translation, Num. 13:27: ואשתעיאו / ve-'ishta'iu; D. STEIN, "A maidservant and her Master's voice: discourse, identity, and Eros in Rabbinic texts," Journal of the History of Sexuality 10:3-4 (2001) pp. 390-391 on R. Yehudah HaNasi maidservant.

${ }^{16}$ RASHI, Eruvin 53b, s.v. בלשון חכמה / be-leshon hokhmah.

${ }^{17} 2$ Ch. 24:14. There is a different interpretation of the word עלת / 'alat; see R. D. Kiмchi, Commentary, 2Ch. 24:14, apud Mikraot Gedolot ed. (Tel Aviv 1954 [in Hebrew]); D. Altschuler, Metzudat Zion - Commentary to Chronicles, 2Ch. 24:14, apud Mikraot Gedolot ed. (Tel Aviv 1954 [in Hebrew]); R. H. BAR HushiEl, Eruvin 53b; RAshi, Eruvin

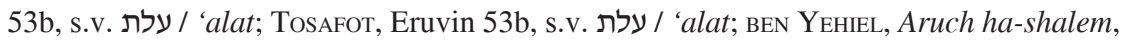
vol. 6, pp. 210-211, s.v. עלת / 'alat; cf. Y. Brand, Ceramics in Talmudic Literature (Jerusalem 1953 [in Hebrew]) pp. 402-404, on the commentary of the Aruch ha-shalem to עלת / 'alat; M. Gross, Y. BARKai and Y. Melamed, Different Readings of the Aggadah (Tel Aviv 2008 [in Hebrew]) pp. 31-32.

${ }^{18}$ Rashi, Eruvin 53b, s.v. נקפת בכד / naqafat ba-kad; Binding Fragment of Bologna, Archive State 15, misses few words of Rashi's explanation.

${ }^{19}$ BAr Hushiel, Eruvin 53b.

${ }^{20}$ BAR Hushiel, Eruvin 53b; Rashi, Eruvin 53b, s.v. יעדי) / (או) yi cede. 
The first part of the story suggests that the maidservant would hint ${ }^{21}$ to the students that they should go home, while the second part indicates that she would hint to them that they could remain, continuing to $\operatorname{sit}^{22}$ in Rabbi's house.

Researchers ${ }^{23}$ have offered conflicting interpretations of the hints in this story, as well as the identity of the one saying these things to the students: Rabbi $^{24}$ or the maidservant - as we shall see.

But the story in the printed version is somewhat different from the versions of the same narrative preserved in various sources; some of these are significant for understanding the story's plot.

\section{THE DIFFERENT VERSIONS OF THE STORY IN VARIOUS SOURCES}

According to the version preserved in the Genizah fragment, when speaking in the idiom of wisdom (as noted, this means resorting to veiled language), Rabbi's maidservant would say this: "Let the ladle strike the jar, let the eagles seek ${ }^{25}$ their nests, and let the crown [cover] of her friend [the adjacent jar] be removed from her [it]."

At times she would say to them: "Let the eagles seek their nests"; and at others [times] she would say: "Let the crown [cover] of her friend [the adjacent jar] be removed from her [it], and let the ladle strike the jar like a vessel plowing the sea."

The wording in the Genizah version leaves it unclear whether the students would go to their homes ("let the eagles fly to their nests"),

${ }^{21}$ S. EIDELSH, Hidushey Maharsha, Eruvin 53b, s.v. בלשון / be-leshon. It is impolite that the maidservant would say directly to the students to go home.

${ }^{22}$ The meaning of the word ליתבון / litevun should be interpreted as 'and sit' as Onqelos Translation to Gen. 34:23 or as R. H. BAR Hushiel, Eruvin 53b: 'and stay' rather than 'and return' as read by S. VALLER and S. RAZABI, Small Talks in the Babylonian Talmud (Tel Aviv 2007 [in Hebrew]) p. 121.

${ }^{23}$ VALLER and RAZABI, Small Talks, p. 121; S. VALLER, "Megamot be'aricha sifrutit shel sugya talmudit, sugyat Eruvin daf 53b-54a-ossef aruch shel sihot hullin," Dafim LeMechkar BeSifrut 14-15 (2006) p. 21 n. 10; S. VALLER, "Women's Talk - Men's Talk: Babylonian Talmud Erubin 53a-54a," Revue des Études Juives 162: 3-4 (2003) pp. 421-445.

${ }^{24}$ BAR Hushiel, Eruvin 53b.

${ }^{25}$ Onqelos' translation Gen. 37:16 מא את בעי / ma at ba'e. 
why the lid should be removed from another wine barrel or jar ("let the crown [cover] of her friend [the adjacent jar] be removed from her [it])." The only way out of the unanswered question seems to be that this version of the text notes an introduction of sorts to the two alternative possibilities in the maidservant's speech, which are spelled out in what she goes on to say later: "at times she would say to them: Let the eagles fly to their nests, and at others [times] she would say to them: Let the crown [cover] of her friend [the adjacent jar] be removed from her [it]." The possibility also remains that the word "or" was omitted in the Genizah version, but it still forms a part of the text in 'En Ya'akov and the version in MS Oxford 366. In addition, according to the Genizah version, the second time the text notes that the maidservant spoke ("and at others [times] she would say..."), there is no mention of whom she addressed, while the first time this is specifically indicated: "at times she would say to them," meaning the students.

The text variants in MS Munich 95 and MS Vatican 109 are incomplete as compared to the text in 'En Ya'akov and MS Oxford 366. In the opinion of some scholars, the version in MS Oxford 366 is what some of the commentators were working with initially; ${ }^{26}$ the idea has found support that MS Oxford 366 is the "correct version" 27 as based on the argument that this version is the "more convenient" one. ${ }^{28}$ Yet the same argument should yield support for the version of the text in 'En $\mathrm{Ya}$ 'akov, which is also the more convenient and detailed variant.

Besides all the versions already mentioned, we should also compare the extant variants available with the version preserved in R. Hananel bar Hushiel (RH), in which we read: "Let the students go to their tents, or let the lid be removed from another barrel, so that they may remain at the wine banquet." That is, "At times he would reply to them: Let the eagles seek their nests; that is, let them go home. And at other times, he would say to them: Let the lid be removed from another barrel and float... in the

\footnotetext{
${ }^{26}$ Rabiinovicz, Dikduke Sofrim, Eruvin 53b, p. 204, n. 60: Apparently that was the version of Rashi and Ha-aruch.

${ }^{27}$ RabBinOvicz, Eruvin 53b, p. 204.

${ }^{28}$ Rabinovicz, Eruvin 53b, p. 204.
} 
barrel like a vessel in the heart of the sea", ${ }^{29}$ so that they may remain at the wine banquet.

$\mathrm{RH}$, too, seems to have been working with a version which included the word "or", similar to what we have seen in 'En Ya'akov and the variant in MS Oxford 366. The version in RH corresponds in part to the text in MS Oxford 366. The two coincide completely in this sentence: "or let the crown [cover] of her friend [the adjacent jar] be removed from her [it]; at [other] times he would say to them... and when he would need, he would say to her..." The version in RH also notes the option of "or" (like the version in 'En Ya'akov). According to the text in RH, Rabbi (=Rabbi Yehudah Ha-Nasi - Rabbi Judah the Prince) is the speaker, rather than the maidservant, as opposed to the version in 'En Ya'akov, where the maidservant speaks.

Similarly, according to the version in RH, Rabbi used to resort to veiled hints in addressing his students in the two opposite situations - and not the maidservant. ${ }^{30}$

The first: when he "would reply to them" (reply to their question?) that they should go home. The second: when he would "say to them" that they should stay "at the wine banquet."

In light of everything said thus far, it becomes evident that there is a difference between the text in RH and that in 'En $\mathrm{Ya}$ 'akov with regard to the identity of the speaker. In the text in RH, Rabbi and not the maidservant is the speaker, while in the version in 'En Ya'akov, the maidservant, not Rabbi, is the one who speaks.

A further difference appears between the version in $\mathrm{RH}$ and that in $\mathrm{MS}$ Oxford 366. According to the RH version, Rabbi would speak directly to the students ("at times he would reply to them... and at other [times] he would say to them...") and not to the maidservant. According to the version in MS Oxford, it turns out that Rabbi would speak to the maidservant ("At times he would say to her... and when he would need, he would say to her"), rather than directly to the students.

\footnotetext{
${ }^{29}$ BAR Hushiel, Eruvin 53b.

${ }^{30}$ See above nt. 21.
} 
Rashi worked with yet another version of the text, which should be considered in addition to the versions mentioned above. Rashi's version clearly also included the word "or". ${ }^{31}$ As noted, this word appears only in the 'En Ya'akov version and in that in MS Oxford 366. Some scholars are of the opinion that Rashi used the same version as the one in MS Oxford 366, but this is not necessarily true, considering that passages are missing in Rashi's commentary which could have been compared to the version in 'En Ya'akov and the one in MS Oxford 366. In addition, there are certain differences between Rashi's version and the one in MS Oxford 366. ${ }^{32}$ Rashi possibly worked with a version of the text identical to the one in 'En Ya'akov, ${ }^{33}$ or a different version similar to the one in 'En Ya'akov or the one in MS Oxford $366 .{ }^{34}$

\section{EXPLAINING THE ARAMAIC ROOT ק.פ / Q.F.Y IN LIGHT OF THE WORD / VE-TITQFEY}

Rashi explains the word ותתקפי / ve-titqfey in this way: "let the ladle float in the jar freely." /q.f.y is then connected to floating. But this interpretation is doubtful; in fact, it may be an addition made to Rashi's own words by copyists - a suggestion further borne out by the fact that in a passage of the binding fragment of Bologna ${ }^{36}$ only the single word "freely" appears. Even so, later Rashi explains the word ותתקפי / ve-titqfey by saying:" תקפי כמו אקפו ידייכו titqfey kemo

${ }^{31}$ Rashi, Eruvin 53b, s.v. יעדי / (או) (o) yi'ede.

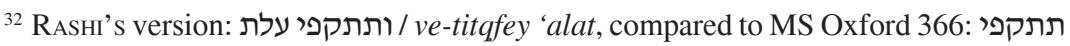

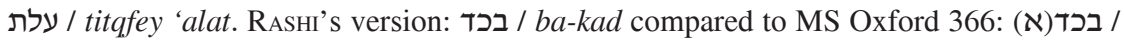
ba-kad(a); see above nt. 13.

${ }^{33}$ IBN HABIB, 'En Ya'akov, Eruvin 53b version: ותתקפי עלת / ve-titqfey 'alat is the same as Rashi's version.

${ }^{34}$ RashI's version (and Binding Fragment of Bologna, Archive State 15): כאילפא ב / $k$ - 'ilfa be-yama contrast to Oxford 366 and IBN HABIB, 'En Ya'akov versions: / ke-’ilfa de-azelah be-yama.

35 RASHI, Eruvin 53b, s.v. ותתקפי / ve-titqfey.

${ }^{36}$ Binding Fragment of Bologna, Archive State 15.

${ }^{37}$ RAsHI, Eruvin 53b, s.v. כאילפא בימא / ke-'ilfa be-yama. 
aqafu yadaikho [titqfey being similar to 'join hands up'] וכמו קפא תהומא ...3a / ve-kemo qafa tehoma [and to 'the abyss frozen']... צח התחום ועלה / tzaf hatehom ve- 'alah ['the abyss float and come upward'] "39,". Rashi's comments indicate that the meaning of the root י ק / q.f.y derives from the notion of floating, to the exclusion of all other possibilities.

But there are three other feasible interpretations still to be considered. The lexicon 'Aruch ha-shalem does, indeed, interpret the root p. p / q.f.y in the sense of 'floating' (from the same origin as / קפא / qafa and similar to Rashi's interpretation), ${ }^{40}$ but he also notes that another explanation is possible (hailing from נקר / naqaf, having the meaning of 'connecting and cleaving', thus indicating that the ladle should be joined (i.e., anchored) in the barrel. ${ }^{41}$

The same is suggested by the interpretation in the Aramaic dictionary in connection with the root י / q.f.y: "to surface at a river's bank... to anchor." 42

An alternative possibility emerges if we compare the text to the way it is translated into Arabic in the commentary by R. Se'adya Gaon (RSG) on the verse: "Stand by your burnt-offering" (Num. 23:3) where the word for "stand by" is rendered by the Arabic قف / qaf. In Arabic, this word forms the imperative of the verb وقف, with the associated meaning of 'stopping' or 'standing'; this would, accordingly, imply that the ladle should stay in one place in the barrel.

There is a difference between the interpretations put forth in the 'Aruch ha-shalem dictionary and in the commentary by RSG. According to the 'Aruch ha-shalem, the ladle should be joined to the barrel by means of any joining apparatus whatsoever, while according to RSG, the ladle should remain in a single place in the barrel without joining.

A third possibility, similar to the one in the commentary by RSG, is implied from the Targum [translation attributed to] Onqelos of the

\footnotetext{
${ }^{38}$ Rashi, Hagigah 16b, s.v. אקפו / aqafu.

${ }^{39}$ RAshi, Sukkah 53a, s.v. קפא תהומא / qafa tehoma.

${ }^{40}$ Ben Yehiel, Aruch ha-shalem, vol. 7, pp. 153-155, s.v. קר / qaf.

${ }^{41}$ Ben Yehiel, Aruch ha-shalem, vol. 7, p.157, s.v. קף* / *qaf.

ק-פ-י 2 Y. SABAR, A Jewish Neo-Aramaic Dictionary (Wiesbaden 2002) p. 281, s.v. $12 q-f-y$.
} 
Biblical passage: קפאו תהומות / qafu tehomot [Ex. 15:8 'the waters of the deep have stood still']. Onqelos renders this as qafo tehome relating the verb to freezing as used of ice. ${ }^{43}$ That is, the waters of the deep froze, turning into a motionless block of ice; in the same way, too, the ladle should remain motionless (frozen) in the barrel, like a vessel in the sea which from a distance appears not to be moving.

According to the interpretation in the 'Aruch ha-shalem, which we have brought up above, there is a connection between the roots ק.د / qafa and ק. / q.f.y. The root ק. / qafa, is also to be encountered in Aramaic. ${ }^{44}$ Even Shoshan's dictionary offers two interpretations of the meaning of the root: ק.د. / qafa in Para. 3 is defined as meaning "to turn to stone, remain motionless," while in Para. 4 it is defined as meaning "to float and rise upward."

Yet another link between the Aramaic word קפא / qafa and the Aramaic root י / q.f.y finds its expression in a different lexicon, which cites as an example the story mentioned at the beginning of the present article, quoting these words from the story: ותקפי עלת / ve-tiqfey 'alat [and let the ladle remain] ${ }^{45}$ (exactly the same as the version in MS Munich 95, which has ותקפי עלת / ve-tiqfey 'alat) as an example to the connection between the Aramaic word קפא / qafa and the Aramaic root י. / q.f.y.

In light of everything said thus far, we can summarize that these three interpretations of the meanings of the root י. / q q.f.y are all different from the interpretation given by Rashi. Rashi favors floating as the correct interpretation, to the exclusion of any other possibility; this is in opposition to the three other options which take the meaning to be joining (anchoring), standing, or standing motionless.

${ }^{43}$ M. Sokoloff, A Dictionary of Jewish Palestinian Aramaic of the Byzantine Period (Ramat-Gan-Baltimore-London 2002) p. 266, s.v. קפי / q.f.y 'to congeal'.

${ }^{44}$ A. Even-Shoshan, HaMilon HeHadash. Otzar Shalem shel HaLashon Ha'Ivrit. Vol. 3 (Jerusalem 1993) p. 1208, s.v. קפא / qafa.

${ }^{45}$ M. Jastrow, A Dictionary of the Targumim, the Talmud Babli, and Yerushalmi, and the Midrashic Literature. Vol. 2 (Brooklyn 1967) p. 1400, s.v. קפא, קפי / qafa, qfy; cf. BEN YeHIEL, Aruch ha-shalem, vol. 7, p. 155, s.v. קר / qaf, קפא / qafa, like floating, what [something that] is floating upward. 
All this makes it possible to explain the Aramaic root ק. / q.f.y by integrating, taking the interpretation in Rashi, who resorts exclusively to the meaning of "floating", as well as the interpretations in the "Aruch hashalem, RSG, and Onqelos, which offer the meanings of floating, joining or anchoring, remaining in place, and standing motionless. According to this integrated interpretation, the meaning of the word ותתקפי / ve-titqfey (or ותקפי / ve-tiqfey) in the story is that the ladle should float upward in the barrel while being joined and anchored to the container, remaining thereafter motionless in place.

\section{EXPLAINING THE ARAMAIC ROOT י כ א.9.F.Y IN LIGHT OF THE ARAMAIC WORD ותתכפי / VE-TITKFEY AS PRESERVED IN THE GENIZAH FRAGMENT}

In the version of the story preserved in the Genizah fragment, this word appears in a somewhat different form: ותתכפי / ve-titkfey (spelled with a $\supset / \mathrm{k}$ - rather than a p/q). Possibly, no difference in meaning exists between the two words, but only a difference in their graphic written representation; it may be that the scribe (who produced the version in the Genizah fragment) wrote the word as he had heard the sound, audiographically, thus yielding the word ותתכפי / ve-titkfey.

But if a difference does obtain between these two words, then the meaning of the root יכ. / k.f.y should be different. The word may be explained based on the Aramaic כฺִָּ / kefa, which has the meaning of overturning and placing on top, identical to the meaning of the Hebrew כפה / kafah, which, according to Even Shoshan's dictionary, ${ }^{46}$ is also to be understood as: "overturning, placing a vessel or the like with its opening facing downwards and its nether part turned upwards."

Whether based on the Aramaic כדִָּּ / kefa or on the Hebrew כפה / kafah, in the story the word ותתכפי / ve-titkfey as deriving from the root י. / k.f.y means to turn over ${ }^{47}$ the ladle and place it over the barrel; al-

כפה Even-Shoshan, HaMilon HeHadash. Vol. 2 (Jerusalem 1993) p. 558, n. 3, s.v I kafah.

${ }^{47}$ Even-Shoshan, HaMilon HeHadash, p. 558, n. 2, s.v. כפוי / kafui. 
ternatively, as per the interpretation in the lexicon of 'Aruch ha-shalem: "it is כפה / kafah [as in the language of the Mishnah], meaning turning an object over so that its front or top side faces downward." ${ }^{48}$ According to both the dictionaries in the 'Aruch ha-shalem and Even Shoshan, in both Hebrew and Aramaic the meaning is the same: to turn over, to place an object in an overturned position.

Numerous examples may be cited to demonstrate that the word כפה / kafah in Hebrew has this meaning of turning an object over so that it faces downwards, and placing it on top of something else, such as, "placing an overturned vessel over it," "placed an overturned mug," "and Rav admits that if he has overturned it, placing it opening downwards... but he has turned the vessel over in order to coat it with pitch..." Similarly, R. Hananel has the wording: "and Rav admits that it's turning the vessel upside down in order to cover it with pitch." 52

Everything thus far considered makes it clear that the meaning of the Aramaic root י א. א.f.y forms a single whole: to overturn an object, pla/ ותתכפי cing it upside down. Based on this root, the meaning of the word ve-titkfey in the story comes down to simply this: to turn the ladle over and to place it over the barrel. The meaning of the word then has no connection whatsoever to floating, joining or anchoring, or staying motionless in a sin-

${ }^{48}$ Ben YehIEL, Aruch ha-shalem, vol. 4, p. 287, s.v. כף / kaf; M. SoKoloff, A Dictionary of Jewish Palestinian Aramaic of the Byzantine Period (Ramat-Gan-Baltimore- London 2002) p. 266, s.v. כפי / kfi: 'to overturn'.

${ }^{49} b$ Shabbat $42 \mathrm{~b}$.

${ }^{50} \mathrm{~b}$ Eruvin 77a; as per the exchange between the words: ספל / sefel (= mug) or / ספסל / safsal; cf. BEN YeHIEL, Aruch ha-shalem, vol. 6, p. 103, s.v. ספל / sefel ('mug'): הספלין / ספסל / sefalin, it is a scribal error and it should be as the printed versions: הספסלין / ha-safsalin; Y. BEN Asher, Tur Orach Haim, Hilchot Eruvin 372:10: ספסל / safsal and n. 35; G. H. Dalman, Aramäisch-Neuhebräisches Handwörterbuch zu Targumim, Talmud und Midrasch (Hildesheim 1967) p. 297, s.v. ספל / sefel, 2. 1. ספסל / safsal; M. JASTROw, A Dictionary of the Targumim, the Talmud Babli and Yerushalmi, and the Midrashim Literature. Vol. 2 (Tel Aviv 1972) p. 1014, s.v. ספל / sefel; on the connection between the words ספל / safsal, see BRAnD, Ceramics in Talmudic Literature (Jerusalem 1953 [in Hebrew]) pp. 388, 392 and 395, nts. 46 and 55.

\footnotetext{
${ }^{51} b$ Eruvin 90b.

${ }^{52}$ BAR Hushiel, Eruvin 90b.
} 
ק.פ. / q.f.y for the word ותתקפי / ve-titqfey, as mentioned above.

\section{SUMmary}

Tractate Eruvin 53b of the Babylonian Talmud records three stories which together comprise a single whole; the unifying characteristic of which is the way all three narratives resort to the "idiom of wisdom," or enigmatic language associated with the speech of each of the story's characters.

The present paper has focused exclusively on the first story, taking it up in connection with our study of the Aramaic word ותתקפי / ve-titqfey and the root י / q.f.y. We have provided a lexicographic analysis of the root of the word, as well as considered another possibility, the root כ. כ / k.f.y, in tandem with the different interpretations offered by the commentators and researchers who have studied these words in the past. The possibilities line up as follows:

1. RSG interprets the root of the word differently from "staying in place;" the same is suggested by the Targum [translation attributed to] Onqelos of the verse קפאו תהומות / qafu tehomot, the waters of the deep have stood still - the standing still is the same as freezing, similar to what can be said of ice which remains in a single place without moving.

2. R. Nathan ben Yechiel, compiler of the 'Aruch ha-shalem dictionary, interprets the root of the word as meaning something different; the meaning derives from notions of "joining or cleaving."

3. Rashi interprets the meaning of the root of the word as associated exclusively with floating.

The various interpretations are quite distinct from each other. We suggest understanding the root ו ותתקפי / q.f. / vetitqfey itself - in a way which integrates all the earlier interpretations: the one offered by Rashi, on the one hand, and those put forth by his predecessors, on the other. That is, the meaning of the word ותתקפי / ve-titqfey is that the ladle should float upward and remain motionless over the ba- 
rrel, while being joined and anchored to the barrel's side - and perhaps also while the ladle is itself overturned, its concavity facing downward, considering what has been noted in connection with the root י כ. / k.f.y. The harmonizing interpretation which we propose makes a contribution to the Talmudic lexicon by explaining the Aramaic word ותתקפי / vetitqfey, as well as the root of the word י ק.9.f.y.

Recibido: 28/07/2015

Aceptado: 19/02/2016 